\title{
Towards Student Centerd Teaching: A New Paradigm
}

\author{
Pragati Sawant \\ Department of Information Technology \\ Rajarambapu Institute of Technology Sangli, India \\ pragati.sawant@ritindia.edu
}

\begin{abstract}
: 21st-century students are demanding an educational system that works for and with them. They are very curious, creative, eager to learn, and willing to try advance and new technologies. Therefore it is necessary to shift from teacher-centred teaching where teacher focused on what they are teaching, to student centered teaching where teacher focused on what students are learning. As a teacher we must act as facilitators who empower and learn from the students. The students should take more active roles as learners and that our roles change, too. This paper discusses Student centric teaching which provides an environment that engages the students allowing the construction of knowledge in a meaningful way by incorporating various interactive methods such as active learning, group learning, collaborative learning, experiential learning, etc. This paper provides more information about studentcentered teaching and offers some insights into how it is implemented for IT Technology Lab course at our Department of Information Technology, K. E Society's Rajarambapu Institute of Technology.
\end{abstract}

Keywords: student-centred teaching; instructorcentred teaching; shift.

\section{Pragati Sawant}

Department of Information Technology

Rajarambapu Institute of Technology Sangli, India

pragati.sawant@ritindia.edu

\section{Introduction}

Traditionally instructors focused on what they are teaching, and not on what the students are learning. Student-centred teachings shift the focus from teachers to the students. In higher education studentcentred teaching approach is increasingly being encouraged. In this approach teachers do not employ a single teaching method. However, a variety of different types of methods that shifts the role of the instructors from givers of information to the facilitator are employed. The instructor creates learning environments that motivate students for learning.

The major concern of traditional teaching approach is: We are teaching. Traditional teaching methods measure declarative knowledge. They neither address depth of understanding nor the skills that the students have acquired.



Figure 1: Teacher-centered Teaching 
Figure1 shows the traditional teacher-centered teaching. It is discipline-specific where students sit in rows and teacher teaches them which is required to pass the examination.

In short,

Teaching refers: Transferring knowledge / experience

Learning refers: Acquiring Knowledge

In order to clarify the concept of Student-centred Learning, I shall compare it with more traditional way of teaching, usually called as 'Teacher-centered Learning' based on certain parameters. This may help you to clarify the notions of 'Student-centered teaching' and 'teacher-centered teaching. Table 1 shows this comparison.

Table 1: Student centered teaching vs. Teacher-centered teaching

\begin{tabular}{|c|c|c|}
\hline Parameters & $\begin{array}{l}\text { Student-centered } \\
\text { Teaching }\end{array}$ & $\begin{array}{l}\text { Teacher- } \\
\text { centered } \\
\text { Teaching }\end{array}$ \\
\hline $\begin{array}{l}\text { Heart of } \\
\text { Educational } \\
\text { System }\end{array}$ & Student & Teacher \\
\hline Knowledge & $\begin{array}{l}\text { Transmitted from } \\
\text { teacher to students }\end{array}$ & $\begin{array}{l}\text { Acquired by } \\
\text { students }\end{array}$ \\
\hline $\begin{array}{l}\text { Learning } \\
\text { Environment }\end{array}$ & Student Centered & Teacher Centered \\
\hline $\begin{array}{l}\text { Student } \\
\text { Participation }\end{array}$ & Passive & Active \\
\hline $\begin{array}{l}\text { Role of } \\
\text { Teacher }\end{array}$ & Leader & Facilitator \\
\hline $\begin{array}{l}\text { Learning } \\
\text { Assessment }\end{array}$ & $\begin{array}{l}\text { One-dimensional } \\
\text { testing Few Tests, } \\
\text { Mainly for grading }\end{array}$ & $\begin{array}{l}\text { Multidimensional } \\
\text { Testing, Many } \\
\text { Tests, for ongoing } \\
\text { feedback }\end{array}$ \\
\hline Emphasis & $\begin{array}{l}\text { Learning correct } \\
\text { answers }\end{array}$ & $\begin{array}{l}\text { Developing } \\
\text { deeper } \\
\text { understanding }\end{array}$ \\
\hline $\begin{array}{l}\text { Performance } \\
\text { Standard }\end{array}$ & $\begin{array}{l}\text { Competitive } \\
\text { approach, } \\
\text { Individualistic }\end{array}$ & $\begin{array}{l}\text { Supportive } \\
\text { approach, } \\
\text { Collaborative }\end{array}$ \\
\hline
\end{tabular}

\section{Student Centered Teaching}

A. Overview
The major concern of student centered teaching approach is: Are they Learning? In student-centered teaching student should be at the heart of our educational efforts. Students and teachers interact equally, instead of listening to the teacher exclusively. Since, group work is encouraged, students learn to collaborate, help and communicate with one another. Figure 2 shows the student-centered teaching approach.

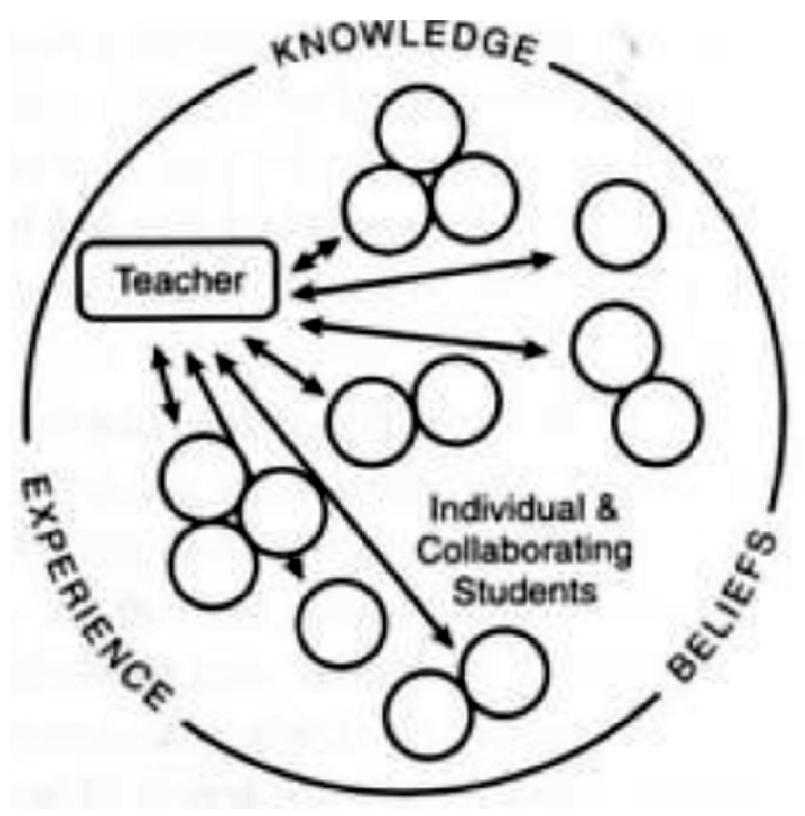

Figure2: Student-Centered Teaching

It implies two main shifts:

1. From thinking about what we teach to how and why we teach something to the students.

2. From thinking about teacher's performance to thinking about the student learning and learning processes.

\section{B. Principles of Student Centered Learning}

"student-centered" teaching gives students choice in content and voice in product. It uses an actual person as an audience and designs learning experiences.

There are 4 principles of student-centered learning which are required to consider as we design curriculum and instructions [4]:

\section{Space}

口 helps to foster creativity in students

口 That is Creative

口 That is Dynamic 
口 That is Mobile

口 That is Emotionally safe

口 That is Cognitively agitating

Place

口 Providing safe and appropriate places to learn and work

口 That students believe they can impact

口 That stirs enthusiasm \& curiosity of students

口 That they connect with in fundamentally "nonacademic" ways

口 That reflects their needs

Choice

( In learning strategies, literacy strategies, etc.

口 In content \& priority

प In media forms and content distribution

․ In audiences for their work

口 In pace \& sequence

Voice

口 That grows as their understanding does

૫ That reflects who they really are

口 In classroom/Laboratory conversations

u In local community as well as around national \& global events

\section{Methodology}

This methodology emphasizes group learning and collaboration. Students work in small groups, access data from the Internet, work together on problems, discuss solutions with their instructor, and present their results.

The instructor serves as a facilitator, Students work in groups to learn, and activities are structured to emphasize collaborative, active, student-based learning

The 3 activities are structured for this lab as follows:

口 Activity A: It gives freedom to the students and honor their passion and interest

口 Activity B: Provides opportunity to serve the society

૫ Activity C: Industry Visit

\section{A. Activity A:Learn New Technology/software}

Objective:

1. To honor student passion and interest

2. To create borderless learning territories for students.

Learning must matter to the learner. This activity gives autonomy and responsibility to students for material they learn. Students learn in different ways and have different learning styles. Students choose what they will learn and how they will learn. It keeps students engaged in their own learning and enabling them to achieve their dreams and goals. This part gives students choice and voice, finding ways to design learning experiences that tap into what students value. Here are five steps which are developed for creating a student-centered learning:

\section{Prepare group of 3 or 4 students}

2. Select the new technology which is not included in curriculum

3. Do detail study of selected technology and develop a utility/application.

4. Prepare Report and present it in front of in-charge faculty.

Table 2 shows some of the technologies/software the stude

n t

Table 2: Sample Technologies/Software's

\begin{tabular}{|l|l|}
\hline Technology/ Software & Description \\
\hline Anti Tracks & $\begin{array}{l}\text { Clean up junk, duplicate } \\
\text { files, erase tracks, eliminate } \\
\text { spam, and protect sensitive } \\
\text { data. }\end{array}$ \\
\hline KeePass & $\begin{array}{l}\text { Open source password } \\
\text { Manager }\end{array}$ \\
\hline presented. & $\begin{array}{l}\text { A mature, open source, } \\
\text { cross-platform, functional- } \\
\text { firstProgramming } \\
\text { Language }\end{array}$ \\
\hline PEARL & Scripting Langualge \\
\hline Komodo Edit & $\begin{array}{l}\text { Free, fast and multi } \\
\text { language code editor }\end{array}$ \\
\hline Ruby & Programming Language \\
\hline 2-D Animation & An android Application \\
\hline
\end{tabular}




\section{B. Activity B: community Services}

Objective: To demonstrate digital literacy as well as social responsibility

As an engineer it is our social responsibility to utilise the knowledge acquired to benefit the people around us. This activity gives great opportunity to students to help the community

The following are the guidelines given to the students:

1. Visit to various colleges/school/Nagarparishad and create awareness about IT

OR

Develop software and donate it to open source community.

\begin{tabular}{|c|c|c|}
\hline $\begin{array}{l}\text { Areas covered } \\
\text { under } \\
\text { Community } 2 \text {. } \\
\text { Services }\end{array}$ & $\begin{array}{l}\text { Name of } \\
\text { Organization } \\
\text { (or } \\
\text { Community } \\
\text { Addressed) } \\
\end{array}$ & $\begin{array}{l}\text { Location } \\
\text { Arrange a } \\
\text { visit of school }\end{array}$ \\
\hline $\begin{array}{l}\text { School } \\
\text { Children }\end{array}$ & $\begin{array}{l}\text { Vijaymala } \\
\text { Ashramshala }\end{array}$ & Kapuskhed \\
\hline $\begin{array}{l}\text { Youth } \\
\text { students }\end{array}$ & $\begin{array}{l}\text { Chate } \\
\text { Coaching t o } \\
\text { Classes }\end{array}$ & \begin{tabular}{|l} 
Islampur \\
\\
\\
RIT.
\end{tabular} \\
\hline $\begin{array}{l}\text { Agriculture } \\
\text { wing table } \\
\text { the Sample } \\
\text { Services }\end{array}$ & $\begin{array}{l}\text { Farmers } \\
\text { Follo } \\
\text { Table } 3 \text { shows } \\
\text { Community } \\
\text { students have }\end{array}$ & $\begin{array}{l}\text { Urun, } \\
\text { Anantnagar \& } \\
\text { Rajbageshwar } \\
\text { areas of } \\
\text { Islampur city }\end{array}$ \\
\hline $\begin{array}{l}\text { Highschool } \\
\text { undertaken. }\end{array}$ & $\begin{array}{l}\text { Shiye } \\
\text { Highschool, } \\
\text { Junior } \\
\text { College, Shiye }\end{array}$ & \begin{tabular}{|l} 
Shiye, \\
Kolhapur
\end{tabular} \\
\hline Education & $\begin{array}{l}\text { Shivkedar, } \\
\text { Vidyalaya }\end{array}$ & Kande \\
\hline Nagarparishad & $\begin{array}{l}\text { Karad } \\
\text { Nagarparishad }\end{array}$ & Karad \\
\hline
\end{tabular}

Table 3: Sample Community Services student have Assessment: The teacher becomes a participant and co-learner in discussion, asking questions and

Areas covered under Community ServicesN a me of Organization (or Community Addressed)Location

\section{Activity C: Industry Visit}

The following are the guidelines given to the students:

1. Identify the industries and get the permission letter.

2. Visit the industry and observe their working culture.

3. Make a report of it and submit to in-charge faculty.

Assessment: The teacher becomes a participant and co-learner in discussion, asking questions about working culture of industry.

\section{Observations And Findings}

The Student-centered teaching approach benefited the students to improve and deepen their understanding about the facts. But it has some drawbacks as well. In this section we will discuss the pros and cons of the methodology which is used to implement student centred teaching.

Advantages of using Student-Centered Teaching

u Students effectively learn communicative and collaborative skills through group work.

u Students learned to complete tasks independently.

口 Students interact with one another and participate actively.

口 Learning skills of the student are developed.

( The roles of instructor became facilitative rather than didactic.

( The responsibility for learning shifts from the instructor to the students.

口 Student-centered teaching method uses assessment as a part of the learning process.

u Learning becomes interesting and enjoyable.

u students retained more of the concepts that they chose to address

૫ Disadvantages of using Student-Centered Teaching

૫ Sometimes group work can become problematic as students prefer to work alone.

u When students are working on different stages of the same project then it becomes difficult for teacher to manage all students .

口 Some students may miss important facts because the teacher doesn't deliver instruction to all students at once. 


\section{Conclusion}

After adopting this methodology it was identified that students get more enthusiastic, motivated and curious to learn new things. Group activities encouraged them to demonstrate creativity, communication, and collaboration. Activity A and B gives them opportunity to learn new technologies and understand social responsibility. Students became capable of accepting more responsibility for their own learning. As future teachers it is our responsibility to care about our student's effective learning and try to teach them from all different aspects.

\section{References}

[1]Blumberg, P. (2008) Developing LearnerCentered Teachers: A Practical Guide for Faculty. San Francisco: Jossey-Bass.
[2]Jaques, D. (2000). Learning in Groups: A Handbook for Improving Group Work. London: Kogan Page.

[3] Marton, F. and S. Booth (1997). Learning and Awareness. Mahwah, New Jersey: Lawrence Erlbaum Associates.

[4] http://www.usciences.edu/teaching/LearnerCentered/

[5]http://www.teachthought.com/learning/4principles-student-centered-learning/ 